\title{
Economic Damage Due to Thryonomys Swinderianus and Atherurus Africanus in Rivers State
}

\author{
Opuogulaya, R* Ekiyor, H. T Aisuene, F and Gbiiah, L. S. \\ Department of Science Laboratory Technology, School of Applied Sciences Kenule Beeson Saro-Wiwa \\ Polytechnic, P.M.B 20 Nigeria
}

\begin{abstract}
The damage done to farm crops by Thryonomys swinderianus and Atherurus africanus in four Local Government Areas of Rivers State; Khana, Gokana, Tai and Eleme was investigated in this research. Structured questionnaire was used to extract information from 100 farmers. Farms were broadly categorized into two for analysis. With an estimation guide list, estimate was made for each raided crop on a farm, an entire farm and all farms. The raided crops include cassava, cocoyam, threeleaf yam, maize, sugar cane, melon, tomato, banana, pineapple and pumpkin. No farm was attacked by A. africanus alone but $54 \%$ of farms were attacked by $\mathrm{T}$. swinderianus alone and $46 \%$ by both animals. The estimated damage to farms attacked by $\mathrm{T}$. swinderianus alone was 332750 naira but 468050 naira for farms attacked by both animals with T. swinderianus accounting for $54.26 \%$ of the damage and A. africanus accounting for $45.74 \%$. The cumulative damage to all farms was 800800 naira; T. swinderianus accounting for $73.26 \%$ of the damage and A. africanus accounted for $26.74 \%$. For all farms, percentage damage to raided crops are; cassava $46.5 \%$, cane sugar $10.75 \%$, maize $10.26 \%$, pumpkin $9.22 \%$, cocoyam $7.54 \%$, melon $7.31 \%$, threeleaf yam $4.74 \%$, pineapple $1.95 \%$, banana $0.96 \%$ and tomato $0.85 \%$. For cassava, pumpkin, cocoyam, maize, melon and cane sugar, damage due to T. swinderianus was higher than that due to A. africanus with an average ratio of 2.7:1; for melon, it was 39:1. Statistically however the cumulative damage due to $T$. swinderianus and that due to A. africanus is not significant. Of the farms investigated, $23 \%$ experienced mild damage, $41 \%$ experienced moderate damage while $39 \%$ experienced severe damage. Average damage was 8008 naira while 0.19 hectares was the average farm size; so farmers lose 8008 naira each year to these "vertebrate agricultural pest" for every 0.19 hectares of farm.
\end{abstract}

Keywords: Farms; Raided crops; Estimated damage; Level of damage; Vertebrate agricultural pest.

DOI: $10.7176 / \mathrm{JBAH} / 9-8-07$

Publication date: April $30^{\text {th }} 2019$

\subsection{INTRODUCTION}

Every year, rodents account for billions of dollars in lost crops as they destroy crops such as rice, sorghum, millet, maize, wheat, coconut, cocoa, oil palm and sugarcane (Ntiamoa-Baidu, 1997; Smith, 2005). Farmers in Ivory Coast have found that rodents are major rice pests (Adesina et. al., 1994).

Thryonomys swinderianus is a great pest of many cultivated crops having been known to do great economic damage to farmers for which the Food and Agricultural Organization, FAO, in 1997 classified it as a vertebrate pest of maize, sugar cane, rice and cassava (Ntiamoa-Baidu, 1997; Merwe, 2000). In some parts of Sierra Leone, greater cane rats are important pest of cassava while in some African regions, it has become an agricultural pest often damaging cassava crops and in West Africa, oil palm plantations (Dahniya, 1981; Child, 2016). Greater cane rat is a major rodent pest of cassava that causes the greatest damage to cassava; it cuts down the stem, chews it and also feeds on the storage roots (James et al., 2000). They raid cassava and yam plantations in farms in local areas and have been termed local pests (Agricultural Nigeria, 2014). In Kanji Lake National Park, Nigeria, Ogunjobi and Adeola 2013, reported that farms in that area were raided by wild vertebrates and rodents accounted for $35.86 \%$ of crop raiding with Thryonomys swinderianus alone accounting for $13.57 \%$ of crop raiding activities. Studies carried out by Uloko et al., 2017 on the evaluation of wildlife pests on rural farms in Benue State, Nigeria, indicated that Thryonomys swinderianus was the most disturbing crop raider accounting for $25 \%$ of crop raiding in the study area.

Both in Europe and Africa, porcupines are considered agricultural pest causing damage to crops and fields (Grubb et. al., 2010). Porcupines eat vegetable crops and are said to be destructive feeders; they dig up and destroy much more food than they eat (De Behind, 2000). In Western Kenya, the wild animal porcupine is recognized as a crop pest (Chitere and Omolo, 1993). The British Broadcasting Cooperation, BBC, 2005 reported that farmers in Kenya's Central Kiambu district have complained that porcupines have so badly damaged their maize crops that they no longer have crops to eat or sell and that they can only use the damaged maize crops to feed cattle. Bourne, 2005 reported that porcupines extensively gnaw branches, twigs and bark of susceptible trees like pine, spruce, elm, poplar, fruit-trees and numerous shrubs and that those whose bark girdle are severely damage are killed. McPhee 2003, also reported that porcupines gnaw the bark of plantation rubber trees, eat corn, pumpkin, cassava, sweet potatoes, young cotton plants and are thus considered agricultural pest. A study of damage patterns to cultivated potatoes by porcupine shows that an estimated 1.3 tons of potatoes was 
damaged per hectare; thus reducing the profitability of potatoes (Alkon and Saltz, 1985). Porcupines also damage vegetables, fruits and succulent plant during summer (Bourne, 2005). Weyerhaeuser, Inc., in 1957 carried out a study in which they said that during its lifetime, a single porcupine could destroy six thousand dollars worth of timber (Olson and Lewis, 1999). Atherurus africanus is known to feed on cultivated crops, feed on the bark and the fleshy tissues of trees (Ellis, 2000). Just like other African porcupines, this species can cause damage to crops and agricultural fields, favoring a number of cultivated roots and fruits, such as cassava, sweet potatoes, bananas and other fruits (Hoffmann and Cox, ,2016).

\subsection{METHODS}

\subsection{STUDY AREA}

This research work was conducted in four Local Government Areas of Rivers State; Eleme, Tai, Gokana and Khana. These Local Government Areas which are East of Port Harcourt are located in the southeastern part of the lower Niger Delta within the coastal and rainforest belt (Amanyie, 2001; Unrepresented Nations \& Peoples Organizations, UNPO, 2017; Okon and Ogba, 2018). This region covers an area of 1046.4 square kilometers and lie between longitude $7^{\circ} 2^{\prime} 00^{\prime \prime} \mathrm{E}$ and $7^{\circ} 18^{\prime} 30^{\prime \prime} \mathrm{E}$ and latitude $4^{\circ} 18^{\prime} 30^{\prime} \mathrm{N}$ and $4^{\circ} 31^{\prime} 00^{\prime \prime} \mathrm{N}$ (Okon and Ogba, 2018). This region experiences two seasons; rainy and dry seasons with rainfall distribution ranging from $2000-$ $3000 \mathrm{~mm}$ per annum, an average temperature of $27^{\circ} \mathrm{C}$ to $35^{\circ} \mathrm{C}$ depending on the season of the year; the relative humidity being between $80-100 \%$ at dawn and 70-80\% during the afternoon (Offodile, 1992; Amechi, 2010; Peter and Ayolagha,2012; Tanee and Albert, 2015) The vegetation of this region is characterized by mangrove swap forest and rich rainforest; the soil type ranges from the poorly drained soils and the well drained coastal plan sand deposits (Amanyie, 2001; Peter and Ayolagha, 2012; Tanee and Albert, 2015; Okon and Ogba, 2018)

The peoples of this region are predominantly Christians with a few involved in traditional belief (United Nations Environmental Program, UNEP, 2016; UNPO, 2017). They are mainly crop farmers and fishing people (UNEP, 2016; UNPO, 2017). The crop farming and fishing occupation of these people have been drastically and dramatically bastardized by oil pollution.

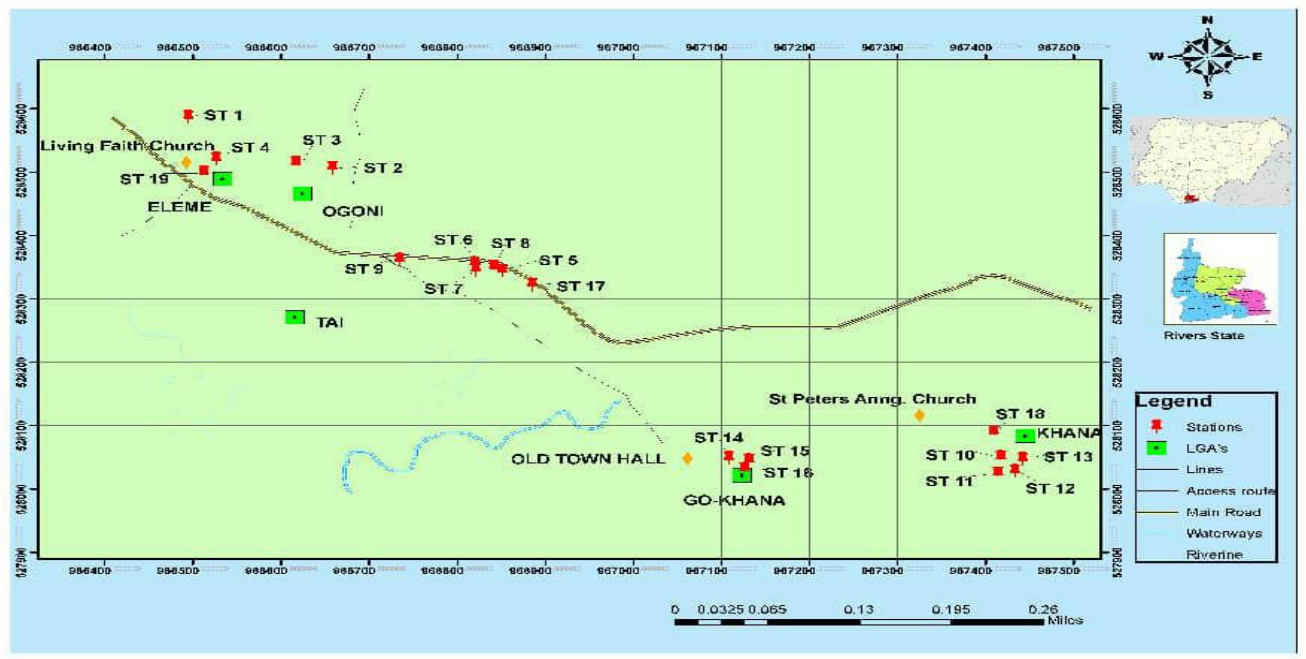

Fig 2.1 Study Map and Sampling sites

\subsection{Estimation of Economic Damage}

A purpose oriented questionnaire was used to extract information from one hundred farmers at random in the four local government areas of Rivers State: Khana, Gokana, Tai and Eleme; twenty five farmers from each Local Government Area. The questionnaire among other things particularly sought to know the size of the farm land; whether or not the farm has a fence; the particular type(s) of crop(s) cultivated by the individual farmer; whether or not they have seen the study animals before and on their farms.

The questionnaire also sought to know the kind if crop(s) raided by Atherurus africanus and Thryonomys swinderianus on their farms and get estimated damage done to each raided crop by porcupine and greater cane rat. The questionnaires were not given to the farmers to fill; the researchers with the aid of guides and information supplied by the farmers filled the questionnaires. The guides led us to the farmers, developed relations with the farmers, scheduled visits and did the work of interpretation.

For estimation of crop damages, the researchers developed an Estimation Guide List; a list that has crop types, quantities and fixed prices. The list was developed thus: possible list of crops planted in the study area was made, the prices of these crops gotten from 3 markets (Nortem Market Khana, Ultra Modern Market Nonwa 
and Eleme Market); average prices for the crops were used. The list was finally shriveled to only crops raided on in farms because of relevance.

Table 2.1 Estimation Guide List

\begin{tabular}{|l|l|l|l|}
\hline Crop (Botanical Name) & Crop (Common Name) & Quantity & Price (In Naira) \\
\hline Manihot esculenta & Cassava & Bagcco Bag & 500 \\
\hline Telfaria occidentalis & Pumpkin & $64 \mathrm{~cm} * 3$ & 50 \\
\hline Colocasia esculenta & Cocoyam & $3 \mathrm{Big} / 4$ Small & $100 / 50$ \\
\hline Zea mays & Maize & $3 \mathrm{Cobs}$ & 100 \\
\hline Cucumeropsis mannii & Melon & 4 Pods $=1 \mathrm{cup}$ & 200 \\
\hline Musa acuminata & Banana & 4 Fingers & 100 \\
\hline Solanum lycopersicum & Tomato & 4 Clenched fist size & 50 \\
\hline Dioscorea batatas & Three leaf yam & $8 \mathrm{~cm} * 3$ & 200 \\
\hline Saccharum officinarium & Cane sugar & $20 \mathrm{~cm}$ & 50 \\
\hline Ananas comosus & Pineapple & $20 \mathrm{~cm}$ by $12 \mathrm{~cm}$ & 300 \\
\hline
\end{tabular}

Estimation of economic damage was done on crops; crops on farms. It was done with the knowledge of remnants reuse and an estimation guide list. Estimation was first done to each raided crop on a farm, then the damage done to a farm. Cumulative damage done to all farms accounted for the economic damage.

$\underline{\text { Sample Calculation }}$

Bariziga Samuel has a 6 plot size $\left(30,000 \mathrm{ft}^{2}\right)$ farm in Gokana and reported that his farm suffers attacked by both animals. Estimation was done thus:

Table 2.2 Sample Estimation of Raided Farm

\begin{tabular}{|l|l|l|l|}
\hline Animal & Crop(s) Raided & Quantity Raided & $\begin{array}{l}\text { Estimated Damage To Each } \\
\text { Crop (in Naira) }\end{array}$ \\
\hline Atherurus africanus & Cassava & 10 of bagcco bag & 5000 \\
\hline & Pumpkin & 24 length of $64 \mathrm{~cm}^{*} 3$ & 1200 \\
\hline & Maize & 30 cobs & 1000 \\
\hline Thryonomys swinderianus & Cassava & 8 of bagcco bag & 4000 \\
\hline & Pumpkin & 32 length of $64 \mathrm{~cm}^{*} 3$ & 1600 \\
\hline & Maize & 60 cobs & 2000 \\
\hline & & Total & $\mathbf{1 4 8 0 0}$ \\
\hline
\end{tabular}

Farms (on the basis of animal raid) were also categorized into: Grade A Farms (those raided by Atherurus africanus alone); Grade B Farms (those raided by Thryonomys swinderianus alone) and Grade C Farms (those raided by both animals).

In each farm grade, Crop(s) raided, number that planted raided crop(s), number that reported damage to crop(s), number that attributed damage to a particular animal and estimated damage done to each raided crop was established.

Farms (on the level of damage) were also categorized into: Mild Damage (damage between 3000 - 5000 naira); Moderate Damage (damage between 5100 - 8000 naira) and Severe Damage (damage from 8100 and above). The categorization of farms on the level of damage was arrived at as a consensus of ten farmers and the researchers.

\subsection{Land Use}

Plot of Land (standard size): 50 by $100\left(5000 \mathrm{ft}^{2}\right) ; 15$ by $30\left(450 \mathrm{~m}^{2}\right)$. Total plots investigated: $411.5 ; 2057500 \mathrm{ft}^{2}$; $191148 \mathrm{~m}^{2} ; 19.115$ hectares; 47.233 acres. Average plot: $4.115 ; 20575 \mathrm{ft}^{2} ; 1911.48 \mathrm{~m}^{2} ; 0.191148$ ha; 0.47234 ac.

\subsection{RESULT AND DISCUSSION 3.1 RESULTS}

The crops raided on in farms is presented in table 3.1 


Table 3.1 Crops Raided On In Farms
\begin{tabular}{|l|l|l|}
\hline Plant (botanical name) & Plant(common name) & Part Eaten \\
\hline Manihot esculenta $* *$ & Cassava & Stem \& tuber \\
\hline Saccharum officinarium $* *$ & Cane sugar & Stalk \\
\hline Telfaria occidentalis** & Pumpkin & Leaves \\
\hline Zea mays** & Maize & Cobs \\
\hline Cucumeropsis mannii $* *$ & Melon & Fruit \\
\hline Cococasia esculenta** & Cocoyam & Tuber \\
\hline Solanum lycopersicum $*$ & Tomato & Fruit \\
\hline Musa acuminata $*$ & Banana & Fingers \\
\hline Anona comosus $*$ & Pineapple & Fruit \\
\hline Dioscorea batatas & Threeleaf yam & Tuber \\
\hline
\end{tabular}

Note: ** Raided by both animals; * raided by porcupine; without asterisks, raided by cane rat.

Farms investigated fell into three categories (based on animal attack). This is presented in table 3.2

Table 3.2 Farm Categories (Based on Animal Attack)

\begin{tabular}{|l|l|l|}
\hline Farm Category & Number of Farms & \% of Farms \\
\hline Grade A (only porcupine attack) & 0 & 0 \\
\hline Grade B (only greater cane rat attack) & 54 & 54 \\
\hline Grade C (porcupine and greater cane rat attack) & 46 & 46 \\
\hline
\end{tabular}

Figure 3.1 present the number of farmers that planted a particular kind of crop and the number that reported raid.

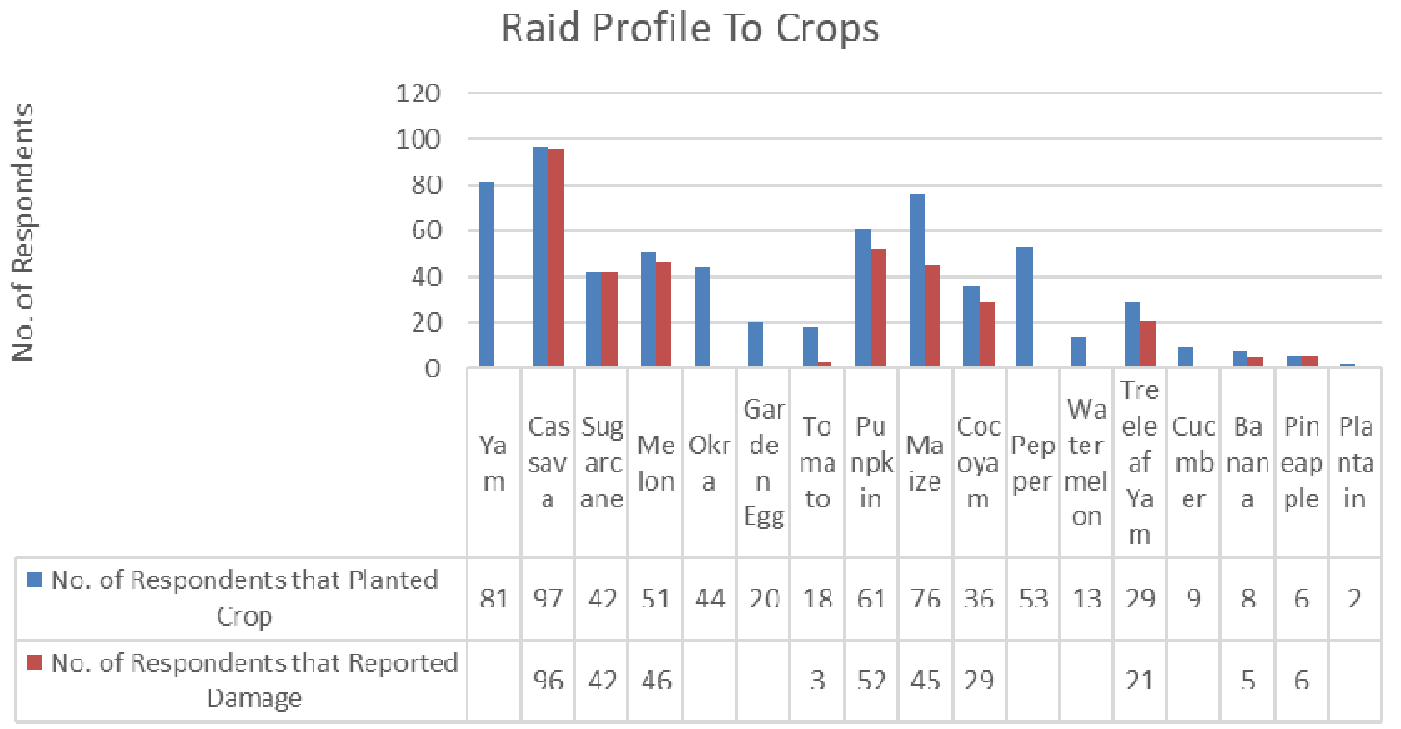

Figure 3.1 Raid Profile To Crops

Figure 3.2 show the raid profile of Grade B farms: only crops raided and the extent of raid is presented in figure 3.2 


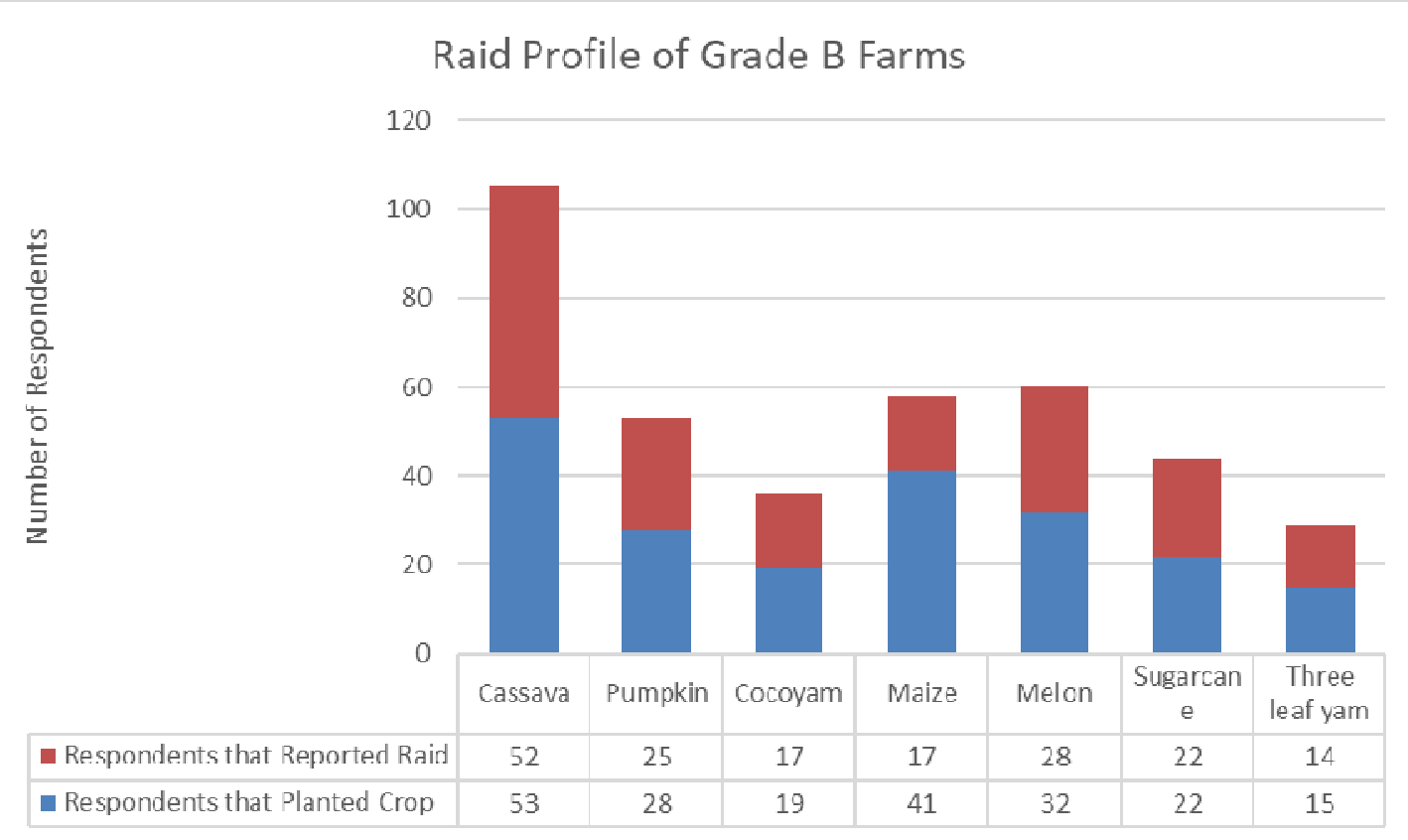

Figure 3.2 Raid Profile of Grade B Farms

Figure 3.3 shows the estimated damage (in naira) done to each raided crop in Grade $B$ farms.

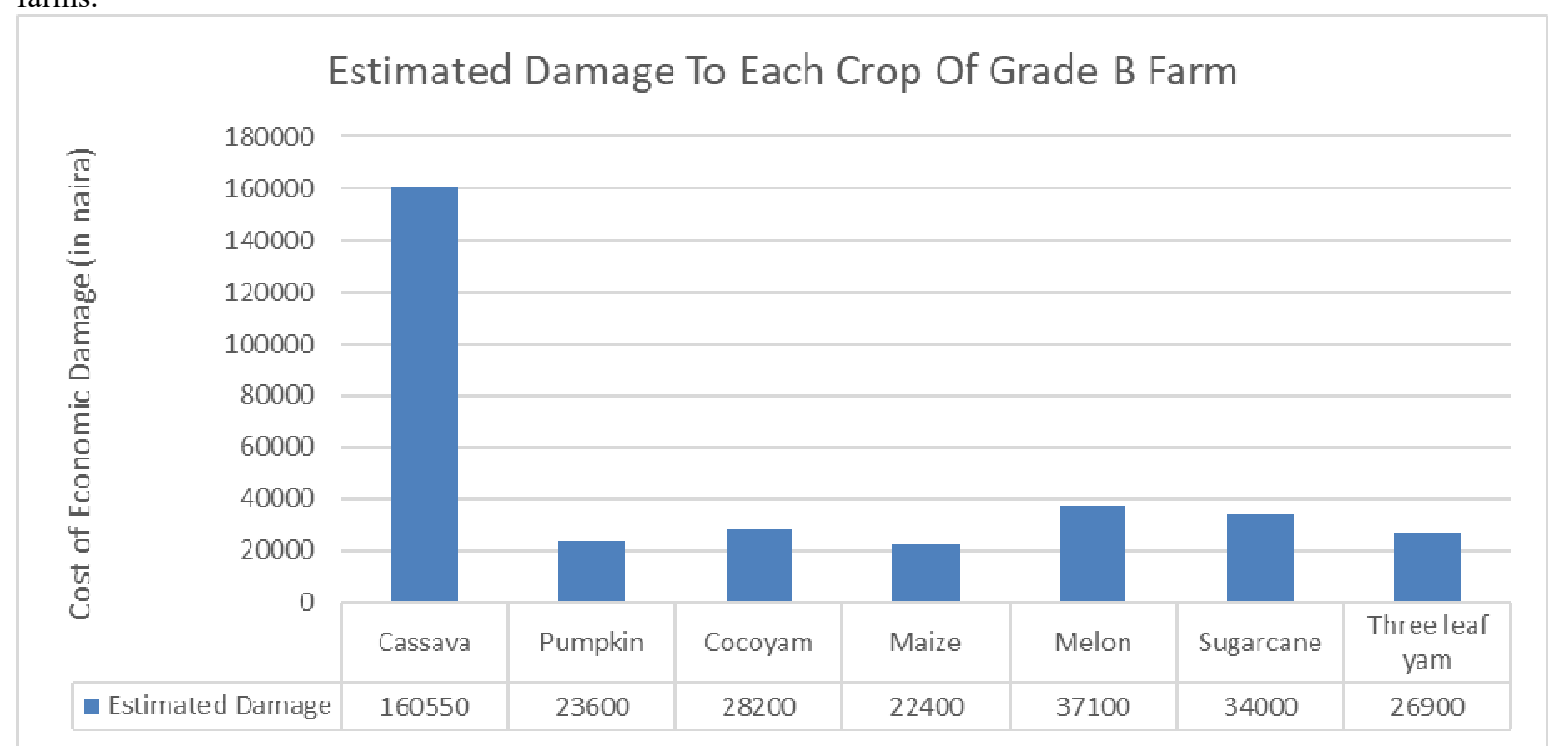

Figure 3.3 Estimated Damage To Grade B Raided Crops

The cumulative damage done to Grade B farms is three hundred and thirty two thousand seven hundred and fifty naira (332750). Figure 3.4 below show the raid profile of Grade $\mathrm{C}$ farms; the number that planted raided crop(s), the number that reported raid and the number that attributed raid to either Thryonomys swinderianus and Atherurus africanus 


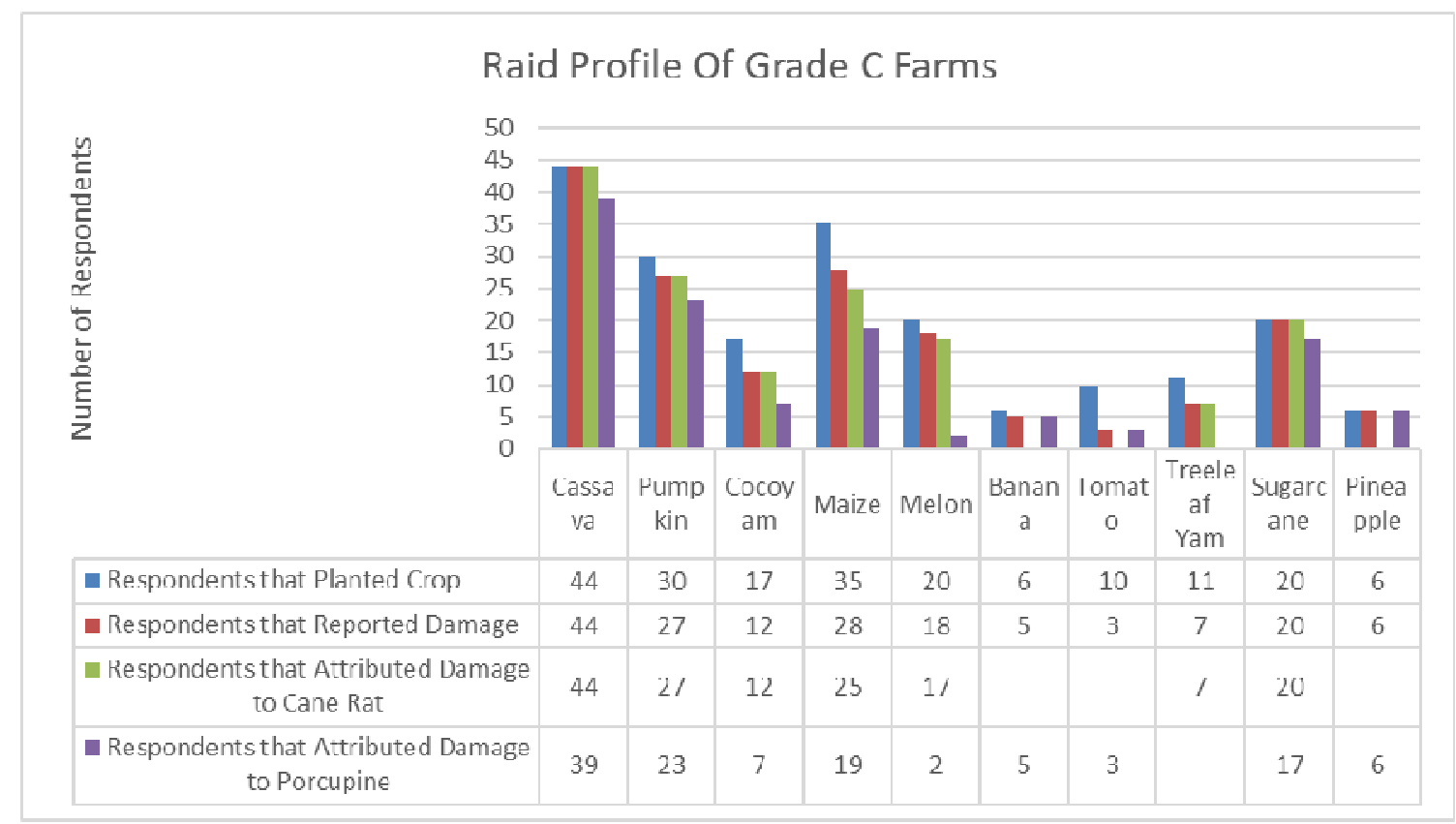

Figure 3.4 Raid Profile Of Grade C Farms

Figure 3.5 present the cumulative damage done to each raided crop in Grade $\mathrm{C}$ farms and that due to the animals.

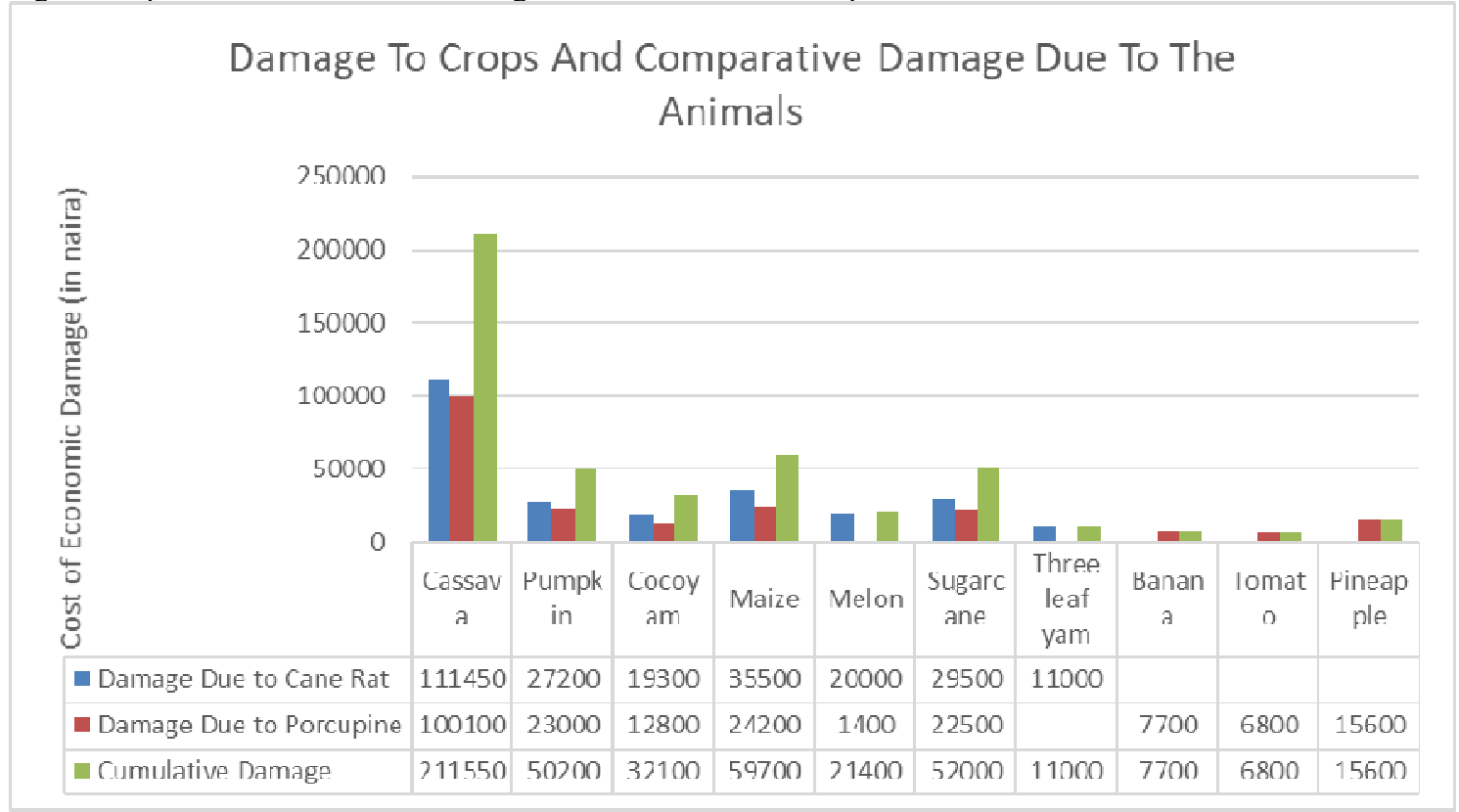

Figure 3.5 Damage To Crops of Grade C

The cumulative damage done to Grade $\mathrm{C}$ farms is four hundred and sixty eight thousand and fifty naira (468050 naira) Thryonomys swinderianus accounting for $54.26 \%$ (253950 naira) and Atherurus africanus accounting for $45.74 \%$ (214100naira). Figure 3.6 shows the relation between the damage due to $T$. swinderianus and $A$. africanus. 


\section{Grade C Farm: Comparative Damage \\ - Damage Due To Cane Rat - Damage Due To Porcupine}

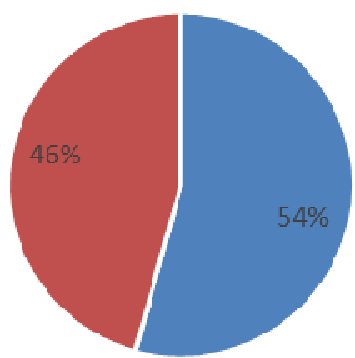

Figure 3.6 Comparative Damage Of Grade C Farms

At 0.01 level of significance and $99 \%$ confidence level, the mean damage done by Thryonomys swinderianus in Grade $\mathrm{C}$ farm $(\mathrm{x}=1670.7 ; \mathrm{n}=152)$ is less than the mean damage done by Atherurus africanus in Grade $\mathrm{C}$ farm $(\mathrm{x}=17769.4 ; \mathrm{n}=121)$; the difference between these mean at 0.05 level of significance and $95 \%$ confidence level is not large enough to constitute statistical significance $\{\mathrm{Zo}(0.923)<\mathrm{Zc}(1.96)\}$.

Figure 3.7 present a comparison between estimated damage to each crop of Grade B and Grade C farms.

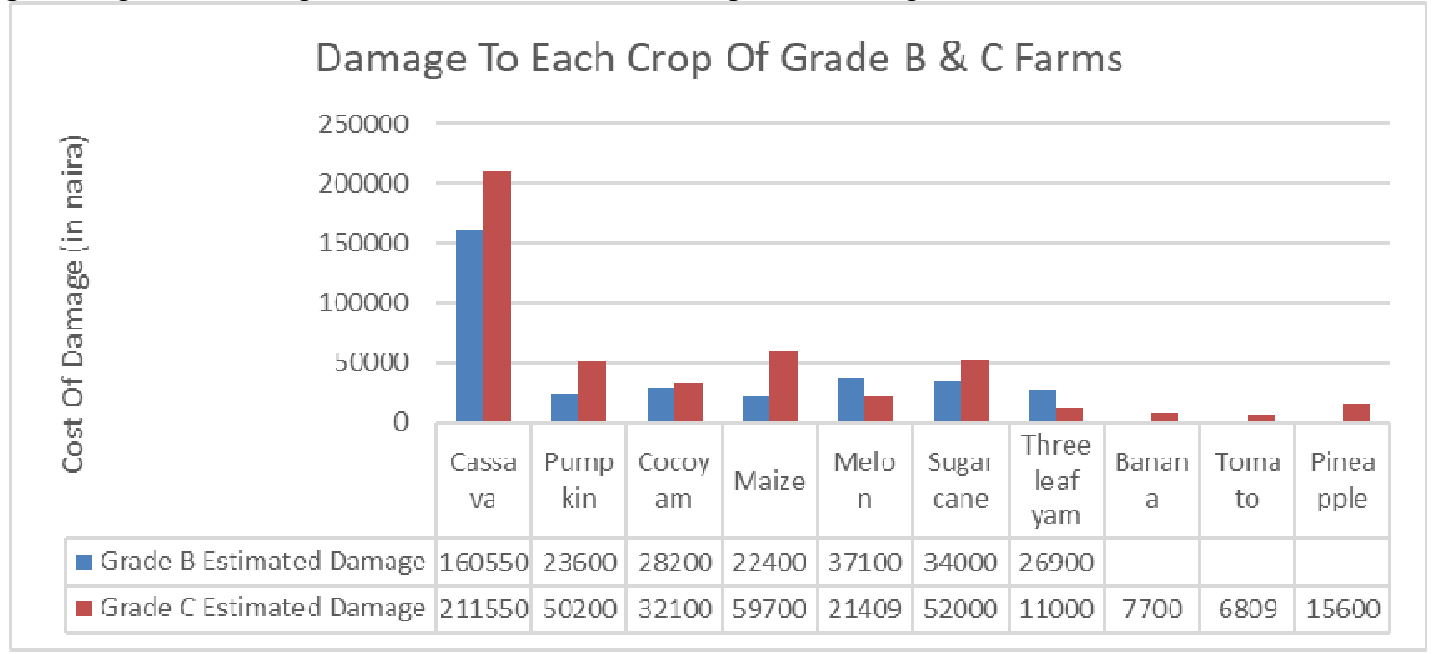

Figure 3.7 Comparative Damage To Crops Of Grades B \& C Farms

A comparison between damage of Grade B farms and Grade C farms acknowledged that at 0.01 level of significance and $99 \%$ confidence level, the mean damage to Grade $\mathrm{B}(\mathrm{x}=1901.4 ; \mathrm{n}=175)$ is higher than the mean damage of Grade $\mathrm{C}$ farms $(\mathrm{x}=1714.5 ; \mathrm{n}=273)$, and the difference between these mean constituted statistical significance $\{\mathrm{Zo}(1.994)>\mathrm{Zc}(1.96)\}$.

Figure 3.8 present the raid profile of all raided farms: the number that planted the raided crop, the number that reported damage and the number that attributed damage to either Thryonomys swinderianus or Atherurus africanus 


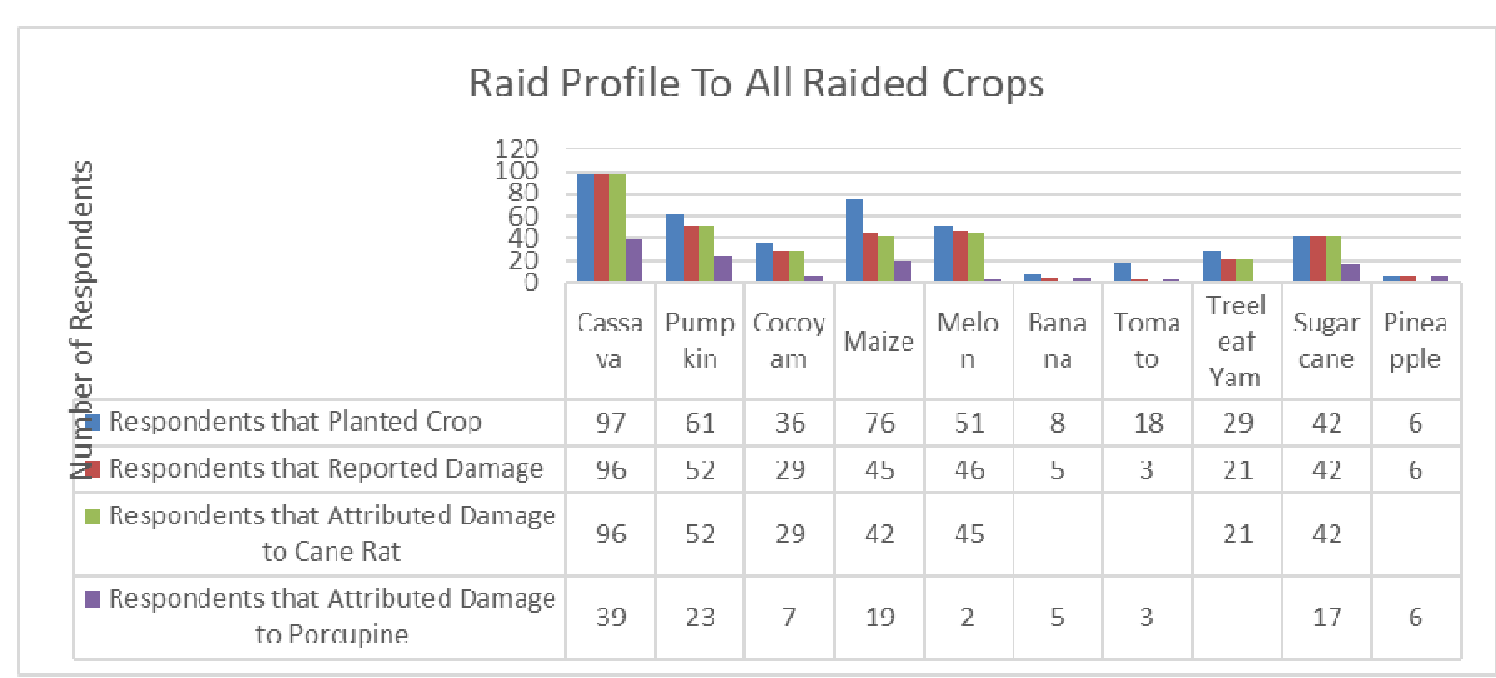

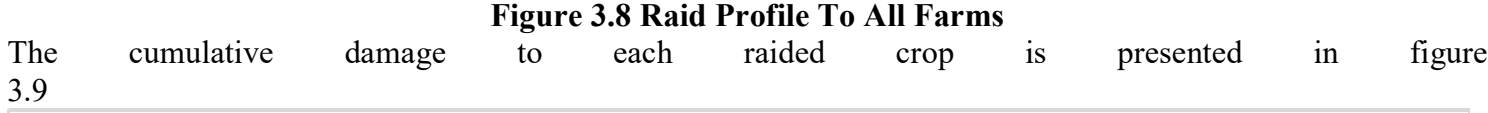

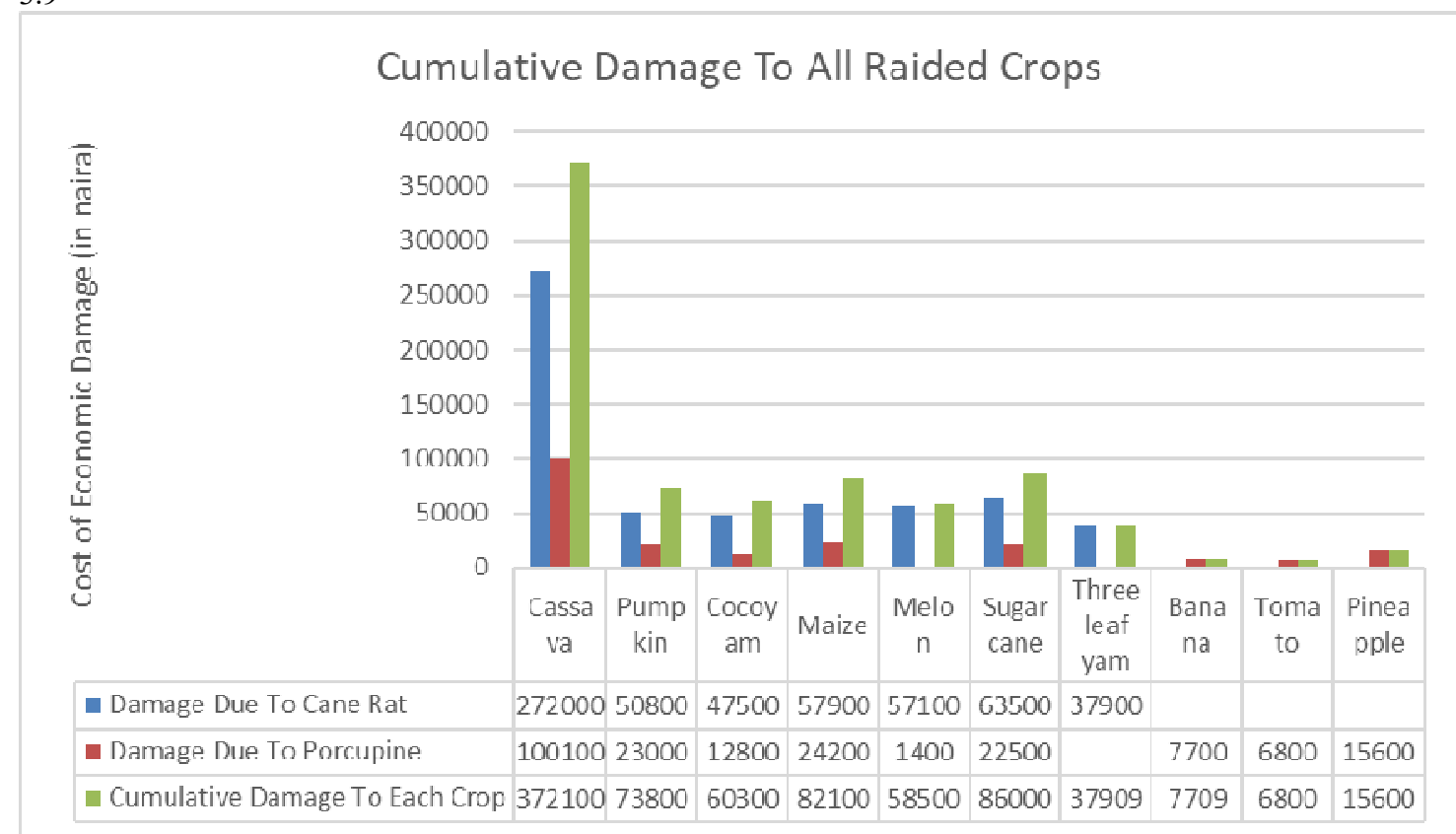

Figure 3.9 Cumulative Damage To Crops

The cumulative damage done to all farms is eight hundred thousand eight hundred naira (800800 naira) Thryonomys swinderianus accounting for $73.26 \%$ of the damage (586700 naira) while Atherurus africanus accounted for $26.74 \%$ of the damage (214100 naira). Although at 0.01 level of significance and $99 \%$ confidence level $(\mathrm{Zc}=-2.33 ; \mathrm{Zo}=0.238)$ the mean damage of Thryonomys swinderianus $(\mathrm{x}=1794.2 ; \mathrm{n}=327)$ is higher than the mean damage of Atherurus africanus $(\mathrm{x}=1769.4 ; \mathrm{n}=121)$, the difference between these mean at 0.05 level of significance and $95 \%$ confidence level $(\mathrm{Zc}=1.96 ; \mathrm{Zo}=0.238)$ is not statistically significant. Figure 4.10 shows the comparative damage between Thryonomys swinderianus and Atherurus africanus. 


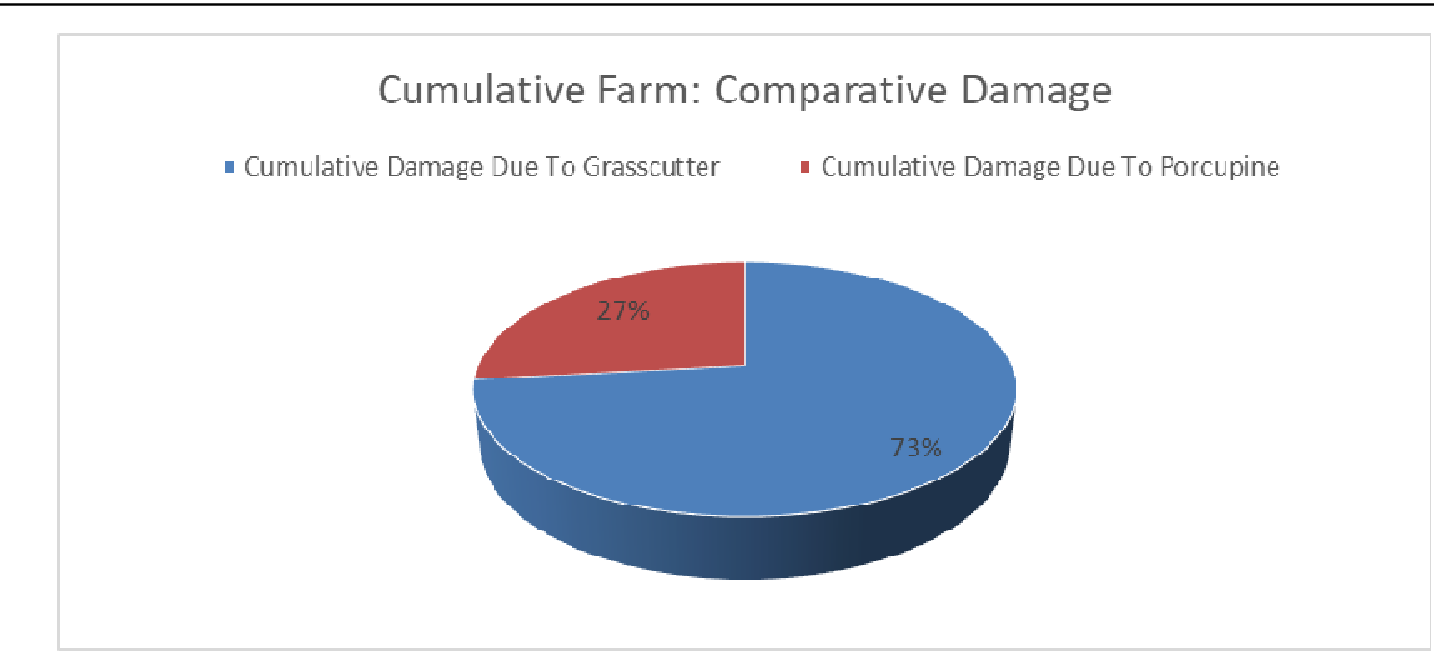

Figure 3.10 Cumulative Comparative Damage

The mean damage to farms as found here is eight thousand and eight naira. Farms were also categorized into three based on the level of damage. Table 4.7 shows this relation.

Table 3.3 Farm category (based on level of damage)

\begin{tabular}{|l|l|l|}
\hline Level of Damage & Number of Farms & \% of Farms \\
\hline Mild (3000-5000 naira) & 23 & 23 \\
\hline Moderate(5100-8000 naira) & 41 & 41 \\
\hline Severe (8100 and above) & 36 & 36 \\
\hline
\end{tabular}

The least damage was found to be three thousand naira while the highest damage was found to be eighteen thousand five hundred naira.

\subsection{DISCUSSION}

The result presented showed that not all planted crops were raided on in farms by the study animals (Fig 3.1). The most raided crop according to the number that planted particular kind of crop was cane sugar and pineapple; all investigated farmers that planted these crops reported raid (Figs 3.1: $3.2 \&$ 3.3). The least raided crop by number that planted a particular kind of crop was tomato (Figs $3.1 \& 3.4$ ). In volume of crops damaged, cassava was by far the highest (Figs 3.1; 3.2; 3.4; $3.7 \& 3.8$ ). Atherurus africanus had a higher range of crops raided on than Thryonomys swinderianus; but Thryonomys swinderianus made higher volume of damage.

There was no farm that was attacked by Atherurus africanus alone, but $54 \%$ of farms were attacked by Thryonomys swinderianus alone whereas $46 \%$ of farms were attacked by both animals (Table 3.2). In the study area, farmers don't live in isolation from hunters; farmers interact with hunters. Farmers have knowledge of vertebrate pest by sights of presence; signs of presence; pattern of feeding and pattern of damage. They know animals that ate their crops by signs of presence, patterns of damage, feed remnants and bite patterns. They infer on these due to sights on farm, interaction with hunters and years of seeing these repeated signs.

For farms raided by Thryonomys swinderianus alone, cane sugar was the most raided crop by number that planted particular kind of crop (22 planted and all 22 reported raid) (Fig 3.2). By volume of damage, cassava was the most damaged crop followed by melon (Figs $3.2 \& 3.3$ ). Three hundred and thirty two thousand seven hundred and fifty naira was the total damage to Grade B farms; cassava alone accounting for $48.25 \%$ of the damage that is one hundred and sixty thousand, five hundred and fifty naira. According to Smith 2005, rodents account for billions of dollars in lost crops every year; the above estimated damage is part of that loss. Thryonomys swinderianus is a great pest of many cultivated crops, a vertebrate pest of maize, cane sugar, cassava; an important pest of cassava, damaging this crop by cutting down the stem and feeding on both stem \& storage root according to Dahniya, 1981; Ntiamoa-Baidu, 1997; James et. al, 2000; Merwe, 2000 and Child, 2016 and the findings of this research is in agreement with all these authorities. For farms attacked by Thryonomys swinderianus and Atherurus africanus (Grade C farms), all the farmers that planted cassava, cane sugar and pineapple reported raid but by volume of damaged crop, cassava was the most damaged (Figs 3.4 \& 3.5). A total of ten crops, cassava, pumpkin, cocoyam, maize, melon, banana, tomato, three leaf yam, cane sugar and pineapple were raided in Grade C farms; Atherurus africanus accounting for all the damages due to banana, tomato and pineapple. Thryonomys swinderianus was responsible for all damages done to three leaf yam. The volume of damage done by Thryonomys swinderianus on Grade $\mathrm{C}$ farms exceeded that due to Atherurus africanus. The estimated damage done to Grade $\mathrm{C}$ farms was four hundred and sixty eight thousand and fifty naira. A. africanus accounting $45.74 \%$ of the damage (214100) while $T$. swinderianus accounted for $54.26 \%$ 
(253950). According to Ntiamoa-Baidu, 1997 rodents destroy crops such as maize, oil palm and cane sugar; yes it is true according to this research work. Chitere and Omolo, 1993; McPhee, 2003 and Grubb et. al, 2010 all reported that porcupines are agricultural crop pest, eat maize, pumpkin and cassava causing damage to crops and field; the findings of this research work is in support of this. Ten crops were raided in Grade $\mathrm{C}$ farms while seven was raided in Grade B farms. Apart from melon, the estimated damage to each crop was higher in Grade C farms than Grade B farms and the estimated damage for Grade C farms was higher than that of Grade B; Grade C farms have two animals that attacked it as compared to one animal that attacked Grade B farms.

The cumulative damage to all farms was found to be eight hundred thousand eight hundred naira, Thryonomys swinderianus accounting for $73.26 \%$ of the damage while Atherurus africanus accounted for $26.74 \%$ of the damage. Of the cumulative damage to all farms, cassava accounted for $46.5 \%$ of damage (372100 naira), cane sugar accounted for $10.75 \%$ of the damage (86000 naira), maize accounted for $10.26 \%$ of the damage ( 82100 naira), pumpkin accounted for $9.22 \%$ of the damage (73800 naira), cocoyam accounted for $7.54 \%$ of the damage (60300 naira), melon accounted for $7.31 \%$ of the damage (58500 naira), three leaf yam accounted for $4.74 \%$ of the damage (37900 naira), pineapple accounted for $1.95 \%$ of the damage (15600 naira), banana accounted for $0.96 \%$ of the damage (7700 naira) and tomato accounted for $0.85 \%$ of the damage (6800 naira). For the raided crops cassava, pumpkin, cocoyam, maize, melon and cane sugar, the damage due to Thryonomys swinderianus was higher than that due to Atherurus africanus with an average ratio of 2.7:1. For melon, the average ratio was 39:1. All damage to pineapple, tomato and banana was due to Atherurus africanus while all damage to three leaf yam was due to Thryonomys swinderianus. Both Ogunjobi and Adeola, 2013 and Uloko et. al., 2017 classified Thryonomys swinderianus as the most disturbing crop raiding rodent; the findings of this research work also showed that Thryonomys swinderianus caused more damage comparatively. This however was not statistically significant.

On the level of damage, $23 \%$ of farms experienced mild damage, $41 \%$ of farms experienced moderate damage while $36 \%$ experienced severe damage (Table 3.3). The least level of damage was found to be three thousand naira (3000) while eighteen thousand five hundred naira (18500) was found to be the highest damage. The average damage was found to be eight thousand and eight naira (8008) and matching this to land used, every 0.19 hectare of farm land losses eight thousand and eight naira to Thryonomys swinderianus and Atherurus africanus every year.

\subsection{CONCLUSION}

The estimated damage to farms attacked by Thryonomys swinderianus alone was three hundred and thirty two thousand seven hundred and fifty naira while the estimated damage to farms attacked by both animals was found to be four hundred and sixty eight thousand and fifty naira (468050) with Thryonomys swinderianus accounting for $54.26 \%$ of the damage and Atherurus africanus accounting for $45.74 \%$ of the damage. The difference between the damage done by Thryonomys swinderianus and Atherurus africanus on farms attacked by both animals was not statistically significant; but statistically significant for farms attacked by both animals and farms attacked by Thryonomys swinderianus alone.

The damage done to all investigated farms, spanning 19.12 hectares was found to be eight hundred thousand, eight hundred naira (800800); Thryonomys swinderianus accounting for $73.26 \%$ of the damage and Atherurus africanus accounted for $26.74 \%$ of the damage. For cassava, pumpkin, cocoyam, maize, melon and cane sugar, the damage due to Thryonomys swinderianus was higher than the damage due to Atherurus africanus with an average ratio of 2.7:1; for melon however it was 39:1. Damages to tomato, pineapple and banana were all due to Atherurus africanus while all damages to three leaf yam was due to Thryonomys swinderianus. Statistically however the cumulative damage due to Thryonomys swinderianus and that due to Atherurus africanus was not big enough to be significant.

A total of $23 \%$ of farms experienced mild damage, $41 \%$ of farms experienced moderate damage while $39 \%$ of farms experienced severe damage. Three thousand naira was found to be the least damage while the highest damage was found to be eighteen thousand five hundred naira. The average damage was found to be eight thousand and eight naira while 0.19 hectares was found to be the average farm size. For every 0.19 hectares of farm, famers thus loss eight thousand and two naira to Thryonomys swinderianus and Atherurus africanus every year. Although farmers in the study area agreed that not all crop raids are due to the study animals, these animals accounted for substantial damages in terms of crop raid to have won for themselves the laurel of "vertebrate agricultural pest".

\section{References}

Adesina, A. A., Johnson, D E and Heinrich, E. A. (1994). Rice Pest in the Ivory Coast, West Africa: Farmers Perceptions and Management Strategies. International Journal of Pest Management Vol 40 Issue 41994. pp 293-299.

Agriculture Nigeria, (2014). Grasscutter. Accessed October 19, 2106 at www.agriculturenigeria.com/farming- 
production/livestock/grasscutter

Alkon, P. U. and Saltz, D. (1985). "Patterns Of Crested Porcupine (Hystrix indica) Damage To Potatoes. Journal of Agriculture, Ecosystem \& Environment Volume 14, Issue 3-4, December 1985 Pgs 171-183.

Amechi, C. (2010). Environmental Studies: Ogoni Land. Report Submitted to the Environmental Affairs Department, Shell Development Company of Nigeria Ltd.

British Broadcasting Corporation (2005). Porcupines Raise Thorny Questions in Kenya. One-minute World News. Accessed June 13, 2017 at BBC.co.UK/2/hil/africa/4157330.stm

Bourne, J. (2005). Control of Porcupine Damage. Alberta Agriculture and Forestry. Accessed November 25, 2017 at www.agric.gov.AB.can/A department/deptdocs.NSF/all/agdex3470

Child, M.F. (2016). Thryonomys swinderianus (errata version published in 2017). The IUCN Red List of Threatened Species 2016: e.T21847A115163896. Downloaded on 14 August 2018.

Chitere, P. O and Omolo, B. A. (1993). Farmers Indigenous Knowledge of Crop Pest and their Damage in Western Kenya. International Journal of Pest Management Vol 39, Issue 2. pp 126-132.

Dahniya, M. T. (1981). Cassava Production in Sierra Leone: Problems and Prospects. Sierra Leone Agricultural Journal 1981. 6 (2): 75-78.

DeBruine, L. (2000). "Hystrix africaeaustralis” (Online). Animal Diversity Web. Accessed November 25, 2016 at http://animal diversity.org/accounts/Hysrix_africaeaustralis/

Ellis, J. (2000). "Atherurus africanus" (Online). Animal Diversity Web. Accessed November 9, 2017 at https://animaldiversity.org/accounts/Atherurus_africanus/

Grubb, P., Amori, G., De Smet, K and Bertolino, S. (2010). The IUCN Red List of Threatened Species 2010: eT10746A3211666. www.iucnredlist.org/details/107463/3 Accessed November 25, 2017

Hoffmann, M. \& Cox, N. (2016). Atherurus africanus (errata version published in 2017). The IUCN Red List of Threatened Species 2016: e.T2353A115061551. Downloaded on 05 August 2018.

James, B., Yanimek, J., Neuenschwander, P., Cudjoe A., Modder, W., Echendu, N and Took, M (2000). Pest Control in Cassava Farms (Booklet). Wordsmithes Printers Lagos, Nigeria.

McPhee, M. (2003). Hystrix cristata (On-line) Animal Diversity Web. Accessed November 25, 2017 at http://animaldiversity.org

Merwe, M. (2000). Tooth Succession in the Greater Cane Rat: Thryonomys swinderianus. Journal of Zoology 251: $531-545$.

Ntiamoa-Baidu, Y. (1997). Wildlife and Food Security in Africa. Food and Agricultural Organization Guide 33. $\operatorname{Pg} 44$.

Offodile, L. (1992). Soils of Niger Delta. Ambio 12:27-38.

Ogunjobi, J. A and Adeola, A. J. (2016). Wild Vertebrate Associated with Crop Raiding Around Kainji Lake National Park, Nigeria. Advanced Tropical Agriculture Vol 21. No. 32016 pp 28-33

Olson. R and Lewis, A. M (1999). Porcupine Ecology and Damage Management Techniques for Rural Homeowners. University of Wyoming. pp 10-12.

Smith, D. (2005). Introduction to the Rodentia. University of Berkeley. Accessed October 12, 2016 at www.ucmp.Berkeley.edu/mammals/rodents

United Nations Environmental Program (2016). About Ogoni Land. Accessed October 12, 2107 at www.unep.org/disasterandconficts/where-we-work/Nigeria/what-we-do/about-ogoniland

Unrepresented Nation \& Peoples Organization (2017). Ogoni Land. Accessed September 11, 2017 at unpo.org/member/7901 